\title{
DEGS1 wt Allele
}

National Cancer Institute

\section{Source}

National Cancer Institute. DEGS1 wt Allele. NCI Thesaurus. Code C104176.

Human DEGS1 wild-type allele is located within 1q41-q42.12 and is approximately $18 \mathrm{~kb}$ in length. This allele, which encodes sphing olipid delta(4)-desaturase DES1 protein, is involved in fatty acid biosynthesis. 